\title{
Hans Jørgen Engbo: Grønlandsk Kriminalret. Foranstaltningerne
}

DJØF Forlag, 1. udgave (223 sider) ISBN 978-87-754-4851-1

E-bog ISBN 978-87-7198-488-0

Det fremgår av forordet at boken har som formål å tjene som lærebok for jusstudiet ved Grønnlands Universitet. Boken skal dekke en av tre deler av strafferetten, nemling om sanksjonene. De øvrige deler av faget er ansvarslæren og læren om de enkelte straffebud.

Boken er inndelt i 13 kapitler. For en som har lite forkunnskap om Grønnlands historie og rettskultur, vekket kapittel 1 - s. 13-35 - som omhandler dette temaet, særlig interesse. Det er helt nødvendig å ha kunnskap om den konteksten reglene fungere i for å forstå et lands regulering. Kapittelet er derfor en nødvendig del av fremstillingen om Grønnlands sanksjonsrett.

Det er tale om et relativt kortfattet kapittel, men det gir et godt bilde av utviklingen: Fravær av en sterk sentralmakt utviklet særegne sanksjoner. Det fantes blodhevn for drap, men også særegne middel som Trommedyst for å løse konflikter. Fra midten av 1700-tallet gjorde samfunnsutviklingen det påkrevd med mer formelle reguleringer, og Engbo beskriver hvordan danske rettsoppfatninger etter hvert fikk innpass på Grønnland.

Likevel er det interessant å merke seg at det er tale om et samfunn som lenge ikke tok i bruk frihetsberøvende sanksjoner. Individualeprenventive hensyn har stått i sentrum. Begrepet straff brukes fortsatt ikke - på Grønnland heter det «foranstaltninger», og fullbyrdelse har i stor grad skjedd i privat regi gjennom private oppholdsverter. Beliggenhet i verden, antall innbyggere og spredt befolkning er nok forhold som er årsak til utviklingen av en særegen rettskultur i Grønnland. Tradisjonell frihetsberøvelse er etter hvert blitt påkrevd, og da gjerne ved at man i en periode har sendt lovbrytere til institusjoner i Danmark.

Kapittel 1 trekker opp de historiske rammene på en god måte. Om jeg skulle fremheve noe som jeg savnet, er det opplysninger om folketall og kriminalstatistikk. Jeg måtte søke på nettet for å finne ut at det er ca. 55000 innbygger på Grønnland. Den særegne rettskulturen må ses i lys av at det er tale om en liten befolkning og små samfunn. Det hadde også vært interessant å fått flere opplysninger om hva som er de dominerende overtredelser.

Kapittel 2 omhandler rettskildene, se s. 37-53. Selv om rettskildelære gjerne undervises i et eget fag og har sine egne fremstillinger, mener jeg at kapittelet forsvarer sin plass i en lærebok om foranstaltningene. Ved siden av de tradisjonelle rettskilder som grunnlov, lov, lovforarbeider, rettspraksis mv. som 
fremstilles helt kort, fokuserer Engbo på de særlige problemstillinger som er BOGANMELDELSE aktuelle i lys av bokens tema. Rettsgrunsetninger og rettsprinsipper som har særlig betydning ved foranstaltningene, som legalitetsprinsippet, likhetsprinsippet, proporsjonalitetsprinsippet mv., blir naturlig nok viet oppmerksomhet. Men også betydningen av Den europeiske menneskerettighetskonvensjon, folkerettslige rettskilder, fremmed rett og «soft law» hvor blant annet FNs minimumsregler for behandling av innsatte er inkludert, løftes frem. En fremstilling som ikke inkluderer dette videre perspektiv ville gitt et ufullstendig bilde av rettskildene som rettsanvenderen står overfor.

Ulike straffeteorier som individualprevensjon, allmennprevensjon, gjengjeldelse mv. tas opp i kapittel 3 - s. 55-73. Slike grunnleggende kunnskaper hører etter min mening hjemme i en fremstilling om foranstaltningene. Engbo relaterer deretter disse teorier og prinsipper til straffgjennomføringen i Grønnland, og gir en oversikt over «foranstaltningsstigen». Kapittelet inneholder også en oversikt over organisering av fullbyrdelsesmyndigheten og iverksettelse av fullbyrdelsen.

De tre påfølgende kapitler redegjør for de alminnelige straffer: kapittel 4 advarsel og bot - s. 75-77, tilsyn og samfunnstjeneste i kapittel 5 - s. 79-88 og kapitel 6 om anbringelse i anstalt, s. 89-155. Det er naturlig at den mest inngripende sanksjonen vies størst oppmerksomet. Kapittel 6 er derfor det mest omfangsrike i boken. Innbringelse i anstalt ble først innført i Grønnland i 1963, og lengstetiden er avgrenset til 10 år, se s. 89. Kapittelet innholder også en redegjørelse for de prinsipper som ligger til grunn for opphold i anstalt, sikkerhets- og ordenshensyn, normalitetshensynet og rettighetsdoktrinen, se s. $91 \mathrm{flg}$. Dette er viktige element i en fremstilling om foranstaltningene. Engbo trekker også inn relevant praksis fra Den europeiske menneskerettighetsdomstol, se s. 104 og s. 122, og ellers sentrale menneskerettigheter, bl.a. artikkel 6 (2) jf. s. 109, artikkel 8 jf. s. 106, s. 136 og s. 141, første tilleggsprotokoll artikkel 3 jf. s. 120. Det gis en fremstilling av de enkelte deler av fullbyrdelsen, se s. 105 flg., slik som mottakelse, fellesskap, arbeid og utdannelse. De særpregede nasjonale forhold gjenspeiles ved at reinsdyrsjakt er en form for beskjeftigelse som kan tas i bruk utenfor anstalt. Jeg er enig med Engbo at dette er et spektakulert eksempel, se s. 115. Kapittelet behandler også fritid, adgang til penger i institusjonen, medinnflytelse, utgang, besøk, brevveksling og telefonnering, bruk av internett, disiplinærsanksjoner, løslatelse mv. Som norsk leser blir man glad for å se at Engbo er vel kjent med den norske reguleringen på området, se s. 124 om helsemessig bistand. Og på s. 150 trekker Engbo inn norsk høyesterettspraksis om nektelse av prøveløslatelse og forholdet til 7. tilleggsprotokoll artikkel 4 om forbudet mot gjentatt strafforfølgning. Også ved brudd på vilkår, trekkes EMK artikkel 6 (2) og norsk praksis inn i fremstillingen, se s. 154.

Forvaring er temaet for kapittel 7, se s. 157-167. Hovedtrekkene i reguleringen kjenner man igjen i norsk rett. Det er grunn til å merke seg at forvaring brukes mer i Grønnland enn i Danmark, se fremstillingen på s. 158. Her be- 
skrives også deler av kriminalitetsbildet, ved at det fremgår at anmeldelse for BOGANMELDELSE sekualforbrytelser er 10 ganger høyere i Grønnland enn i Danmark. Som nevnt hadde jeg gjerne sett at man fikk presentert mer av kriminalitetsbildet $i$ kapittel 1. Om forfatteren hadde hatt behov for å gjenta noen sentrale tall og størrelser i tilknytning til fremstilling av de enkelte sanksjoner, hadde nok leseren vært overbærende med det. Også i dette kapittel trekkes EMD`s praksis inn der det tas opp problemstillinger som aktualiserer menneskerettslige spørsmål, se s. 163, s. 165 og s. 167. Ellers er det nyttig å få innsikt i de særlige spørsmål som oppstår ved at noen forvaringsdommer gjennomføres i Danmark, se s. 165-166.

Foranstaltninger overfor særlige grupper behandles i kapittel 8, se s. 169178. Det er her tale om barn og pyskisk syke. Det er helt i tråd med fremstillingen i foregående kapitler at internasjonale rettskilder som barnekonvensjonen - s. 169 - og EMK - s. 178 - brukes aktivt i fremstillingen.

Kapittel 9 er et kort kapittel om konfiskasjon - s. 179-180. Også kapittel 10 om valg og utmåling av foranstaltning er kort, se s. 181-185. Benådning fremstilles også helt kort i kapittel 11 - s 187-189.

Klageadgang er tema for kapittel 12, se s. 191-197. Så vel administrativ klage som adgang til å domstolsprøvelse tas opp. Også klageorgan som ombudsmannen mv. blir kort omtalt. Bokens avsluttende kapittel - kapittel 13 - omhandler bistand til dømte gjennom bistansdverge, pasientrådgiver og rettshjelp, se s. 199-205. Avslutningsvis har boken registre over forkortelser, litteratur, forarbeider/betenkninger, avgjørelses- og stikkordsregister med sidetall, se s. 207-223.

Som nevnt er det tale om en lærebok. Omfanget er tilpasset deldisiplinens vekting i studiet, se s. 11. Det er alltid vanskelig å vurdere hvor dypt man skal gå i de enkelte spørsmål, og Engbo har rett i at man også innenfor dette rettsområdet er nødt til å supplere lærebøker med forarbeider mv. dersom man skal nå helt i dybden. Jeg synes likevel at forfatteren har gitt et godt innsyn i foranstaltningene i Grønnland og de nærmere rammer for gjennomføringen. Den som har kjenneskap til norsk straffegjennomføringsrett vil nikke gjenkjennende til mye av det som er behandlet. Boken trekker på en utmerket måte inn internasjonale menneskerettigheter, men også andre lands rett. Dette er etter min mening en klar styrke ved boken. Vektingen av de ulike tema som tas opp fremstår som balansert. For meg var det både spennende og interessant å stifte kjennskap til Grønnlandsk rett på dette området gjennom en godt disponert og velskreven fremstilling.

Asbjørn Strandbakken

Professor dr. jur., Det juridiske fakultet, Universitetet i Bergen 